\title{
About the Stylistic Adaptation of Turkish Loanwords in Macedonian
}

\author{
Keti Miteva-Markovikj, M.A. \\ South East European University, Tetovo, Macedonia
}

Doi:10.19044/esj.2018.v14n20p55 URL:http://dx.doi.org/10.19044/esj.2018.v14n20p55

\begin{abstract}
In a long period of their developmental paths, the Balkan languages have been in continuous contact with each other and have had mutual interference, by which their linguistic structures in a large extent have approximated with the aim of a better intelligibility among the speakers of those languages. Within the lexis, the Turkish language played a dominant role primarily because of the 500-year reign of the Ottoman Empire. All the Balkan languages, especially the Macedonian language, enriched their lexical fund with a large number of Turkish loanwords from all domains of human life. Some of the words made one's way into the domain of archaic and dialectical lexis, however one group of words remained functional in contemporary expressions. Within this text, several Turkish lexical loanwords in the Macedonian language are scrutinized, as well as by analyzing examples, their shift in the stylistic register and increased expressiveness within the contemporary Macedonian language are analyzed. The analyzed examples are from author's personal corpora and are collected through the oral communication, print and digital media. Selected examples will serve to analyze and to prove semantic and stylistic shift in the spoken register of the contemporary Macedonian language.
\end{abstract}

Keywords: Macedonian language, Turkish loanwords, stylistic adaptation

\section{Introduction:}

In linguistics, it is known that the Balkan languages throughout their centuries-old development in a multilingual and multicultural environment have approximated their structures and have created common models that have enabled easier communication between the speakers that have led to the creation of the Balkan Linguistic Community (Asenova, 1989). In his book "Balkan Linguistics Studies", Petar Hr. Ilievski (1988) lists several structural features that are possessed by most of the Balkan languages, such as: the postpositive article, the double definition of the object, partial or complete 
rejection of postpositive case indicators, bringing closer their functional fields of the (spatial) prepositional systems, restructuring of the verbal categories, establishment of similar models within the modality, approximation of the models for the expression of the future, distribution of the periphrastic constructions with esse and habere, as well as many others. Friedman (2015) explains that on dialectological level there are even more structural features common for Balkan dialects. In this context, the Macedonian language is considered to be the most Balkanized language within the Balkan linguistic community (Vidoeski, 1998). In addition to these structural features, the Macedonian language in its development, and especially in the Ottoman Empire period, accepted a large number of lexical elements from the Turkish language, which then adapted them to its lexical system (Koneski, 1981).

\section{I.:}

Turkish lexical elements in the Macedonian language have been treated in several monographs, dictionaries, articles, master's and doctoral dissertations, by which special emphasis has been put on the treatment of the Turkish loanwords in the folk speeches where their representation is the greatest. The monograph "Turkish lexical elements in the Macedonian language" written by the Academician Olivera Jašar-Nasteva (2001) provides an overview of a large number of Turkish loanwords in the Macedonian language as well as their phonetic and morphological adaptation. The author categorizes the Turkish loanwords into many domains such as flora, fauna, medicine, house arrangement, trade and crafts, clothing, spiritual life, and so on. From the overview, one can see how great the influence of Turkish language on the lexicon of the Macedonian language was and largely this lexis was enriched with words from many domains of human life.

In the contemporary Macedonian language, a large part of those Turkish loanwords are already becoming archaic and are increasingly receiving some stylistic expressiveness. Hereinafter, we will look at several lexemes from the Turkish language that, over time from neutral, became very stylishly colored. This primarily refers to the contemporary Macedonian language, and this accommodation is even more expressed in the spoken Macedonian language.

In the following text we will analyze examples from personal corpora collected through the oral communication, print and digital media. Selected examples will serve to analyze and to prove semantic and stylistic shift in the spoken register of the contemporary Macedonian language.

Thus, for example, the lexeme 'derece' in the monograph of JašarNasteva (2001) in the Macedonian language was borrowed in the original form (derece) and denotes a 'degree, state'. In the Digital Dictionary of the 
Macedonian language for this lexeme the following meanings occur: degree, state, position.

In today's contemporary Macedonian language examples can be found where this lexeme moves to the stylistic register and besides the basic meaning, it also receives a negative sign with the meaning of 'low grade, low / poor state'.

Examples:

1. Како дојдовме до ова дереџе?

2. Потегот на ММФ е очекуван, бидејќи тие точно знаат на кое дереџе е Македонија...

3. Н К Ное дереџе е денеска наставникот?

4. Десет причини зошто Грција е на ова дереџе.

5. „Скопски пазар“ падна на дереџе да работи само за каматите на банките...

6. Охридскиот СДСМ критикува: болницата на дереџе на селска амбуланта.

As can be seen from the examples, the Turkish lexeme 'derece' from its neutral meaning of 'degree, state' in the contemporary Macedonian language becomes strongly stylistically marked with negative connotation and it is used in contexts where the purpose is to underline and mark the negativity, that is, to emphasize the meaning of 'low degree / poor state'.

Other examples can be listed in which the Turkish lexeme demek, which was borrowed and accepted in the Macedonian language, gets strong stylistic coloration. In the monograph of Jašar-Nasteva (2001), the lexeme 'demek' has the meaning of 'it means, accordingly.' She claims: "As in the Turkish language, so in the Macedonian language 'demek' has the function of words that lead in a sentence such as: "'Demek ..." This shows that this lexeme is of neutral meaning, similar to the Macedonian word 'it means'. In the Digital Dictionary of the Macedonian language, this lexeme occurs as a modal word with the meanings: it means, that is, let's say, let's suppose. It was this modal thread that enabled this lexeme to gain a stronger stylistic meaning in the contemporary Macedonian language and from a neutral word became a strongly stylishly colored word.

Examples:

1. $\quad$ Ги извади парите, демек ќе плаќа.

2. Бранко демек сака да си оди, а демек не му даваат!

3. „Либертас“ е демек невладина, а перела пари за власта?

4. Тој во очај призна дека грешел, ама демек помалку од другите.

5. Аристотел демек го учел Александар за демократија.

6. Владата демек се „бори“ против семејно насилство, а жртвите не можат да ги платат правните трошоци.

7. Ние демек се браниме, тие демек напаѓаат.

8. Мурињо демек нема да купи нов дефанзивец.

9. Соседите демек не не сакаат, а трчаат на гости кај нас!

From the above given examples it can be noted that the meaning of the Turkish lexeme 'demek' has completely shifted its basic meaning of "it means, therefore" to the stylistic register with a completely opposite meaning. In all 
of these given examples, the lexeme 'demek' contains the meaning of 'as if', that is, something that is not true, but an assumption by which the speaker does not believe in the truthfulness of the given statement and gets a bit of reserved. Thus, in all cases we would be able to replace the word 'demek' with 'as if' and again to receive the same information. The use of this Turkish lexeme with the meaning of 'as if' greatly enhances the stylistic expressiveness and gives a special negative connotation in relation to the credibility of the statement.

The next lexeme that we are going to analyze is related to the borrowings within the verbal system in which Turkish lexical loanwords played a major role. Namely, it is known that the Turkish language also influenced the borrowings within the verbal systems of the Balkan languages (Polenaković, 2007). Here we could list several verbs of the following types:

\begin{tabular}{|c|c|c|c|c|}
\hline $\begin{array}{l}\text { Turkish } \\
\text { azdîrmak }\end{array}$ & $\begin{array}{l}\text { Macedonian } \\
\text { аздиза (-ува) }\end{array}$ & $\begin{array}{l}\text { Aromanian } \\
\text { azdisire }\end{array}$ & $\begin{array}{l}\text { Albanian } \\
\text { azdisë }\end{array}$ & $\begin{array}{l}\text { meaning: } \\
\text { збесна }\end{array}$ \\
\hline bayîlmak & балдиса & băldisire & bajalldis & $\begin{array}{l}\text { малакса, } \\
\text { се умори }\end{array}$ \\
\hline begênmek & бендиса & bindisire & begenis & (ce) допадне \\
\hline kandîrmak & кандиса & căndisire & kandis & $\begin{array}{l}\text { се согласи, } \\
\text { наговори }\end{array}$ \\
\hline kurmak & курдиса & curdisire & kurdis & навие, намести \\
\hline dalmak & далдиса & dîldisire & dalldis & $\begin{array}{l}\text { устреми, } \\
\text { навали, одлучи се }\end{array}$ \\
\hline uymak & ујдиса & uidisire & uidis & $\begin{array}{l}\text { разбере се, } \\
\text { договори, среди }\end{array}$ \\
\hline
\end{tabular}

The mode of adaptation of these verbs is almost identical in all Balkan languages (Skok, 1971). In the spoken (nominal, verbal, adjectival) basis, the Turkish suffix 'di' for the past is added, then the Greek suffix for the aorist 'si' is added, and then the appropriate personal or infinitive suffix is also added, whereas in Macedonian, this goes one more step further by adding the suffix for imperfectivization -ува-, with which these verbs fully integrate into the visual system of the Macedonian language (бендисува, иашардисува, ујдисува, бојадисува.....).

In addition to the verbs that in Macedonian and other Balkan languages adapt in the same way, there are also a considerable number of verbs that got into their basic form such as: арчи, есапи, муабети, пишмани, (се) инати, батали, борџи, докусури, and other.

For the purpose of analysis within the framework of the stylistic adaptation here we will treat the verb арчи. This verb derives from the Arabic word that denotes "cost", which word entered into the Macedonian lexical system through the Turkish language (Škaljić, 1989). This lexeme got completely adapted in the verbal system of the Macedonian language through the form of the word арчи with the same meaning as 'spends (money)'. In the 
Digital Dictionary of the Macedonian Language, this verb occurs with the following meanings: 1 . Spends money. 2 . Consumption, consumes something. In the contemporary Macedonian language more examples can be encountered when this verb is used with an emphasized stylistic expressive meaning, whereby the negative component is more emphasized. Examples:

1. Граѓаните ќе му даруваат на Харадинај 204 вратоврски, да не арчи од плата.

2. Си вградил додатни кочници, за да не ги арчи гуртните додека слегува од Пониква.

3. Јакимовски арчи 20.000 денари дневно за гозби и ручеци од џебот на граѓаните.

4. За секој економски промотор се арчи по милион евра годишно.

5. Судијката го искара државното правобранителство дека го арчи судот на судењето на Демири од Левица.

6. $\quad$ Македонецот ем сиромав, ем арчи многу струја.

7. $\quad$ Ги доарчи парите од куќата.

8. Tрајановски на сакал да поарчи ниту денар за ново парче мебел.

9. Microsoft ќ поорчи 10 милијарди за да го одржи Yahoo.

10. СДСМ брзо и безвезно изарчи голем политички и општествен капитал.

11. Во минатата година успеа да изарчи рекордни десет милиони евра.

From the analysis of the above examples it can be noted that from the Turkish borrowed noun harç, which word, as we mentioned earlier, came into the Turkish language from Arabic, and from which word in the Macedonian language were formed not only the verb арчи, but also some prefixed verbal derivatives such as: доарчи, поарчи , изарчи... They are also included in the Macedonian language system with the addition of prefixes -по, -из, -до, with which the corresponding verbs in the past are formed (verb forms that show finished actions), whereas with the suffix ува, some corresponding continuous verbs (verb forms that show incomplete actions) are formed (поарчипоарчува, изарчи-изарчува,......). From a stylistic point of view, in all these examples, the author of the text chose the Turkish loanword арчи instead of the Macedonian word троши (spends). We consider that this is done exactly from stylistic reasons, in which the Turkish loanword wants to achieve greater expressiveness and gives a certain negative connotation. In this way, the neutral meaning of the word " арчи " is shifted into the stylistic register and in the contemporary Macedonian language it begins to be used with a meaning of "spending too much, spending unnecessarily".

\section{Conclusion:}

From all the above mentioned, it appears that the Turkish language still has an impact on the lexical system of the Macedonian language, but not in the context of its own lexical fund, but, above all, in terms of greater expressiveness and stylistic usage of the contemporary Macedonian language. In the period of the convergent development of the Balkan language community, a large part of the Turkish loanwords stagnated in several domains 
of the Macedonian language lexicon, and they constantly enriched and approximated the intelligibility with the rest of the Balkan languages. In today's development of the Macedonian language, those Turkish loanwords systematically pass into archaisms or remain only in dialectical use, whereas a significant part continues to adapt and shift into the stylistic register of contemporary Macedonian language. These analyzed lexems in particular have achieved that, that is, they have continued to function in the contemporary Macedonian language as well with a changed meaning, which in most cases have negative connotation and a strong stylistic color and with all these features they increase the expressiveness of the expression to a great extent.

\section{References:}

1. Asenova, P. (1989). Balkansko Ezikoznanie. Sofija: Izdatelstvo nauka i izkustvo.

2. Friedman, A. V. (2015). Macedonian studies 2. Skopje: Makedonska akademija na naukite i umetnostite.

3. Ilievski. Hr. P. (1988). Balkanoloski lingvistički studii (so poseben osvrt kon istoriskiot razvoj na makedonskiot jazik). Skopje: Institut za makedonski jazik.

4. Jasar-Nasteva, O. (2001). Turskite leksicki elementi vo makedonskiot jazik. Skopje: Makedonska akademija na naukite i umetnostite.

5. Koneski, B., (1981). Gramatika na makedonskiot jazik. Skopje: Kultura.

6. Polenakovic, H. (2007). Turskite elementi vo aromanskiot. Skopje: Makedonska akademija na naukite i umetnostite.

7. Skaljic, A. (1989). Turcizmi u srpskohrvatskom jeziku (sesto izdanje). Sarajevo: Svjetlost.

8. Skok, P. (1971). Etimologijski rječnik hrvatskoga ili srpskoga jezika. Zagreb.

9. Vidoeski, B. (1998). Dijalektite na makedonskiot jazik, Tom 1-3. Skopje: Makedonska akademija na naukite i umetnostite. 